\title{
Ecotoxicity testing and environmental risk assessment of iron nanomaterials for sub- surface remediation - Recommendations from the FP7 project NanoRem
}

Hjorth, Rune; Coutris, Claire ; Nguyen, Nhung; Sevcu, Alena ; Gallego-Urrea, Juliean Alberto; Baun, Anders; Joner, Erik

\section{Published in:}

Chemosphere

Link to article, DOI:

10.1016/j.chemosphere.2017.05.060

Publication date:

2017

Document Version

Peer reviewed version

Link back to DTU Orbit

Citation (APA):

Hjorth, R., Coutris, C., Nguyen, N., Sevcu, A., Gallego-Urrea, J. A., Baun, A., \& Joner, E. (2017). Ecotoxicity testing and environmental risk assessment of iron nanomaterials for sub-surface remediation -

Recommendations from the FP7 project NanoRem. Chemosphere, 182, 525-631.

https://doi.org/10.1016/j.chemosphere.2017.05.060

\section{General rights}

Copyright and moral rights for the publications made accessible in the public portal are retained by the authors and/or other copyright owners and it is a condition of accessing publications that users recognise and abide by the legal requirements associated with these rights.

- Users may download and print one copy of any publication from the public portal for the purpose of private study or research.

- You may not further distribute the material or use it for any profit-making activity or commercial gain

- You may freely distribute the URL identifying the publication in the public portal 


\section{Accepted Manuscript}

Ecotoxicity testing and environmental risk assessment of iron nanomaterials for subsurface remediation - Recommendations from the FP7 project NanoRem

Rune Hjorth, Claire Coutris, Nhung H.A. Nguyen, Alena Sevcu, Juliàn Alberto Gallego-Urrea, Anders Baun, Erik J. Joner

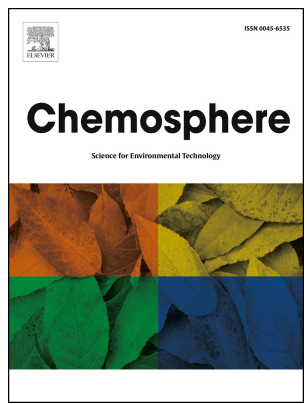

PII: S0045-6535(17)30764-6

DOI: 10.1016/j.chemosphere.2017.05.060

Reference: $\quad$ CHEM 19275

To appear in: $\quad E C S N$

Received Date: 17 February 2017

Revised Date: 1 May 2017

Accepted Date: 10 May 2017

Please cite this article as: Hjorth, R., Coutris, C., Nguyen, N.H.A., Sevcu, A., Gallego-Urrea, Julià.Alberto., Baun, A., Joner, E.J., Ecotoxicity testing and environmental risk assessment of iron nanomaterials for sub-surface remediation - Recommendations from the FP7 project NanoRem, Chemosphere (2017), doi: 10.1016/j.chemosphere.2017.05.060.

This is a PDF file of an unedited manuscript that has been accepted for publication. As a service to our customers we are providing this early version of the manuscript. The manuscript will undergo copyediting, typesetting, and review of the resulting proof before it is published in its final form. Please note that during the production process errors may be discovered which could affect the content, and all legal disclaimers that apply to the journal pertain. 


\section{Ecotoxicity testing and environmental risk assessment}

2 of iron nanomaterials for sub-surface remediation -

3 Recommendations from the FP7 project NanoRem

4 Rune Hjorth $^{\mathrm{a}^{*}}$, Claire Coutris ${ }^{\mathrm{b}}$, Nhung H.A. Nguyen ${ }^{\mathrm{c}}$, Alena Sevcu ${ }^{\mathrm{c}}$, Juliàn

5 Alberto Gallego-Urrea ${ }^{\mathrm{d} 1}$, Anders Baun ${ }^{\mathrm{a}}$ and Erik J. Joner ${ }^{\mathrm{b}}$

$6 \quad$ *Corresponding Author: ruhj@env.dtu.dk

$7 \quad{ }^{a}$ Department of Environmental Engineering, Building 115, Technical University of

8 Denmark, Kgs. Lyngby, 2800, Denmark

$9{ }^{\mathrm{b}}$ Department for Environment and Natural Resources, Norwegian Institute of Bioeconomy

10 Research, Høyskoleveien 7, NO-1431 Ås, Norway

$11{ }^{\mathrm{c}}$ Institute for Nanomaterials, Advanced Technologies and Innovations, Technical

12 University of Liberec, Studentská 2, 46117 Liberec, Czech Republic

13 d Department of Environmental Sciences, Norwegian University of Life Sciences,

14 Fougnerbakken 3, 1430 Ås, Norway

15

16 Abstract

17 Nanoremediation with iron (Fe) nanomaterials opens new doors for treating

18 contaminated soil and groundwater, but is also accompanied by new potential

19 risks as large quantities of engineered nanomaterials are introduced into the

20 environment. In this study, we have assessed the ecotoxicity of four

21 engineered $\mathrm{Fe}$ nanomaterials, specifically, Nano-Goethite, Trap-Ox Fe-

22 zeolites, Carbo-Iron ${ }^{\circledR}$ and FerMEG12, developed within the European FP7

${ }^{1}$ Present address: Department of marine sciences, University of Gothenburg, Box 100, SE-405 30 Gothenburg, Sweden 
23 project NanoRem for sub-surface remediation towards a test battery

24 consisting of eight ecotoxicity tests on bacteria (V. fisheri, E. coli), algae ( $P$.

25 subcapitata, Chlamydomonas sp.), crustaceans (D. magna), worms (E. fetida,

26 L. variegatus) and plants (R. sativus, L. multiflorum). The tested materials are

27 commercially available and include Fe oxide and nanoscale zero valent iron

28 (nZVI), but also hybrid products with Fe loaded into a matrix. All but one 29 material, a ball milled nZVI (FerMEG12), showed no toxicity in the test

30 battery when tested in concentrations up to $100 \mathrm{mg} / \mathrm{L}$, which is the cutoff for

31 hazard labeling in chemicals regulation in Europe. However it should be

32 noted that $\mathrm{Fe}$ nanomaterials proved challenging to test adequately due to their

33 turbidity, aggregation and sedimentation behavior in aqueous media. This

34 paper provides a number of recommendations concerning future testing of $\mathrm{Fe}$ 35 nanomaterials and discusses environmental risk assessment considerations 36 related to these.

37 Keywords: Nanoremediation, Iron nanomaterials, Ecotoxicology, nZVI, 38 Environmental Risk Assessment, NanoRem

$40 \quad 1$ Introduction

41 Innovation in nanotechnology introduces new treatment options for

42 environmental remediation of organic compounds (notably chlorinated 43 solvents) and heavy metals in soil and groundwater (Karn et al., 2009; 
44 Mueller et al., 2012). Especially iron (Fe) based nanomaterials have shown a

45 potential for remediation due to a larger specific surface area and 46 corresponding increased reactivity compared to micro-scale and larger $\mathrm{Fe}$

47 materials traditionally used for remediation of contaminated sites (Wang and

48 Zhang, 1997). Nanoscale zerovalent iron (nZVI) has received most of the

49 attention as it is highly reactive compared to the bulk ZVI used in permeable 50 reactive barriers (Henderson and Demond, 2007). Remediation with nZVI has

51 been claimed to represent a faster, cheaper and a potentially more effective

52 treatment option than current ex situ and in situ methods (Yan et al., 2013).

53 However, nanomaterials engineered to remediate polluted soil and 54 groundwater may constitute a risk to the environment as they are injected into 55 the subsurface in large quantities (Grieger et al., 2010). As such this could 56 represent a worst case scenario when considering possible negative 57 environmental effects of manufactured nanomaterials. Nanoremediation in 58 general seems associated with high uncertainty both in relation to its potential 59 environmental risks, but also towards its field scale efficacy (Grieger et al., 60 2015). Uncertainty with regards to the potential environmental impacts of $\mathrm{Fe}$ 61 nanomaterials hampers their use and has partly been the reason for the 62 limited implementation of $\mathrm{Fe}$ nanomaterials in remediation (Bardos et al., 63 2014), although no major environmental impacts have been reported in the 64 first decade of field deployments with $\mathrm{Fe}$ nanomaterials (Mueller et al., 65 2012). 
66 Several publications in recent years have evaluated the ecotoxicity of $\mathrm{Fe}$

67 nanomaterials, particular nZVI materials, with NANOFER STAR,

68 NANOFER 25 and 25 s being the most common commercially available

69 particles. In these publications the focus has been on aquatic and terrestrial

70 ecotoxicity (Keller et al., 2012; Marsalek et al., 2012; Saccà et al., 2014; El-

71 Temsah et al., 2016) and in general effect concentrations as low as $0.5 \mathrm{mg} / \mathrm{L}$

72 to above $2.5 \mathrm{~g} / \mathrm{L}$ have been reported, demonstrating considerable variation in

73 ecological response to Fe nanomaterials.

74 A range of Fe nanomaterials has been developed in the European FP7 project

75 NanoRem (Taking Nanotechnological Remediation Processes from Lab Scale

76 to End User Applications for the Restoration of a Clean Environment, for

77 more information see nanorem.eu) in order to extend the spectrum of

78 treatable soil and groundwater contaminants from halogenated organics to

79 non-halogenated substances and non-reducible metals. Contrary to the three

80 materials mentioned above, the potential ecotoxicity of the materials

81 developed in NanoRem have not previously been tested. These materials are

82 currently available on the international marked (see Table 1). Common for all

83 materials is that if they are to be used in field-scale remediation, their

84 production volume will easily reach 1 metric ton per year (Mueller et al.,

85 2012). In this case, they will have to be registered under the European

86 chemical legislation REACH, which will be accompanied with data

87 requirements on ecotoxicity. The data generated will feed into the general 
88 hazard identification of the nanomaterials and form the basis for a generic

89 risk assessment (i.e. a hazard classification according to the classification,

90 labeling and packaging (CLP) regulation). It is important to emphasize that

91 this risk assessment does not directly relate to the safety of injecting said

92 material into an aquifer or a contaminated soil. Such a task is done in a site-

93 specific risk assessment, which is outside the scope of this study.

94 Test organisms and endpoints in the ecotoxicology test battery were chosen

95 to include representatives for both terrestrial and aquatic environments as $\mathrm{Fe}$

96 nanomaterials may spread, in worst case scenarios, to both terrestrial and

97 aquatic habitats (Grieger et al., 2010). The ecotoxicity tests were also

98 selected to include standardized tests to ensure general regulatory acceptance

99 of test results as well as non-standardized tests to broaden the test basis with

100 respect to modes of exposure and modes of action, and to enhance the

101 likelihood of seeing biological responses within the range of particles and

102 concentrations tested. The aim of the paper is to provide ecotoxicity data for

103 four newly developed Fe nanomaterials and the paper also highlights current

104 challenges in doing adequate hazard identification and environmental risk

105 assessment of $\mathrm{Fe}$ nanomaterials. Finally, recommendations for future

106 ecotoxicity testing of Fe nanomaterials are provided. 
1082 Materials and Methods

$109 \quad 2.1$ Nanomaterials

110 Samples of Fe nanomaterials for ecotoxicity testing were obtained directly

111 from the manufacturers within the NanoRem project. A full list and

112 characterization of the nanomaterials is seen in Table 1.

$113 \quad 2.1 .1$ Dispersion of nanomaterials for toxicity testing

114 Dispersions of powder $\mathrm{Fe}$ nanomaterials were made according to the

115 description provided by the manufactures. Due to testing constraints (e.g.

116 infeasibility to degas exposure media) for the aquatic standard tests (on $V$.

117 fischeri, P. subcapitata and D. magna), all nanomaterial powders were

118 dispersed as described for magnetite.

119 Carbo-Iron $^{\circledR}$ For $100 \mathrm{~mL}$ of a stock suspension at $10 \mathrm{~g} / \mathrm{L}, 20 \mathrm{~mL}$ of a $10 \mathrm{~g} / \mathrm{L}$

120 carboxymethyl cellulose (CMC) solution was added to $80 \mathrm{~mL}$ of test medium

121 and degassed with $\mathrm{N}_{2}$ for an hour. Then, $1 \mathrm{~g}$ of test material was added to the

122 solution under $\mathrm{N}_{2}$ flow, and mixed for 10 min with a high-shear mixer.

123 Dilution series were prepared under regular aerobic conditions and used right

124 away.

125 Trap-Ox Fe-zeolites A stock suspension with a zeolite concentration of 25

$126 \mathrm{~g} / \mathrm{L}$ was prepared by dissolving $2.5 \mathrm{~g} \mathrm{CMC}$ in $50 \mathrm{~mL}$ deionized water by

127 heating the mixture to $70^{\circ} \mathrm{C}$ with stirring for an hour. Then, $2.5 \mathrm{~g} \mathrm{Fe}$-zeolite 
128 in $50 \mathrm{~mL}$ deionized water was sonicated for $15 \mathrm{~min}$ and the CMC solution

129 and zeolite suspension were mixed and sonicated for additional $15 \mathrm{~min}$.

130 Magnetite Magnetite, received as powder, was suspended in deionized water

131 and mixed for 10 minutes with a high-shear mixer. Subsequent dilutions

132 series in exposure media were prepared and used right away.

133 Suspensions Nano-Goethite was provided as a stable suspension and was

134 diluted directly from the sample into the exposure media. However, the

135 FerMEG12 were additionally sonicated for 15 minutes due to sedimentation.

$137 \quad 2.2$ Characterization of stock suspensions

138 Dynamic Light Scattering (DLS) measurements of aqueous suspensions

139 (deionized water) from $10 \mathrm{mg} / \mathrm{L}$ to $10 \mathrm{~g} / \mathrm{L}$ test material were performed on a

140 Malvern Zetasizer ZS (Malvern instruments Ltd, Worcestershire, UK)

141 equipped with a laser source at a wavelength of $633 \mathrm{~nm}$. Zeta-averaged

142 hydrodynamic diameters and size distributions were determined using the

143 "multiple narrow modes (high resolution)" algorithm supplied by Malvern.

144 Measurements were done in triplicates of 5 runs with autocorrelation

145 functions of 10 seconds. The same instrument was used for the measurements

146 of electrophoretic mobility and the Smoluchowski approximation was used

147 for determining zeta-potentials. Three measurements with 5 runs per 148 measurement were obtained. 
149 Nanoparticle Tracking Analysis (NTA) measurements of the hydrodynamic

150 diameter of individual particles suspended in deionized water at a

151 concentration of $10 \mathrm{mg} / \mathrm{L}$ to $10 \mathrm{~g} / \mathrm{L}$ were done on a Nanosight LM10

152 (NanoSight Ltd, Amesbury, UK). 
153 Table 1 Characterization of the pristine Fe nanomaterials. Magnetite is not used for remediation in NanoRem but was chosen as a 154 control in this study. The listed information is obtained from the manufacturer.

\begin{tabular}{|c|c|c|c|c|c|c|c|}
\hline Name & Description & $\begin{array}{l}\text { Development } \\
\text { Status }\end{array}$ & $\begin{array}{l}\text { Mode of } \\
\text { remediation }\end{array}$ & Form & $\begin{array}{l}\text { Chemical } \\
\text { composition }\end{array}$ & $\begin{array}{l}\text { Average } \\
\text { primary } \\
\text { particle size } \\
(\mathrm{nm})\end{array}$ & $\begin{array}{l}\text { Specific surface } \\
\text { area }\left(\mathrm{m}^{2} / \mathrm{g}\right)\end{array}$ \\
\hline FerMEG12 & $\begin{array}{l}\text { Zero-valent Fe } \\
\text { mechanically } \\
\text { ground through } \\
\text { ball milling }\end{array}$ & $\begin{array}{l}\text { Field tested } \\
\text { and } \\
\text { commercially } \\
\text { available }\end{array}$ & Reduction & Suspension & $\begin{array}{l}15-30 \% \mathrm{Fe} \\
70-85 \% \\
\text { monoethylene } \\
\text { glycol }\end{array}$ & - & $12-18$ \\
\hline Carbo-Iron ${ }^{\circledR}$ & $\begin{array}{l}\text { Composite of } \\
\text { activated } \\
\text { carbon and } \\
\text { zero-valent Fe }\end{array}$ & $\begin{array}{l}\text { Field tested } \\
\text { and } \\
\text { commercially } \\
\text { available }\end{array}$ & $\begin{array}{l}\text { Adsorption } \\
+ \\
\text { Reduction }\end{array}$ & Powder & $\begin{array}{ll}30.3 \% & \mathrm{Fe}_{\text {tot }} \\
20.5 \% & \mathrm{Fe}^{0} \\
13.1 \% & \mathrm{Fe}_{3} \mathrm{O}_{4} \\
55 \pm 1 \% & \mathrm{C}_{\text {tot }}\end{array}$ & $13440 \pm 20$ & 594 \\
\hline Magnetite & $\begin{array}{l}\text { Fe oxides } \\
\left(\mathrm{Fe}_{3} \mathrm{O}_{4}\right)\end{array}$ & $\begin{array}{l}\text { Precursor for } \\
\text { NANOFER } \\
\text { STAR }\end{array}$ & - & Powder & $\mathrm{Fe}_{3} \mathrm{O}_{4}$ & - & - \\
\hline $\begin{array}{l}\text { Nano- } \\
\text { Goethite }\end{array}$ & $\begin{array}{l}\text { Fe oxides } \\
\text { stabilized with } \\
\text { humic acids }\end{array}$ & $\begin{array}{l}\text { Field tested } \\
\text { and } \\
\text { commercially } \\
\text { available }\end{array}$ & $\begin{array}{l}\text { Adsorption } \\
+ \\
\text { Oxidation }\end{array}$ & Suspension & $\begin{array}{l}\text { 'pure' FeOOH } \\
\text { with organic } \\
\text { coating }\end{array}$ & $220 \pm 20$ & 140 \\
\hline $\begin{array}{l}\text { Trap-Ox Fe- } \\
\text { zeolites }\end{array}$ & $\begin{array}{l}\text { Nanoporous } \\
\text { aluminosilicate } \\
\text { loaded with } \\
\mathrm{Fe}(\mathrm{III})\end{array}$ & Premarket & $\begin{array}{l}\text { Adsorption } \\
+ \\
\text { Oxidation }\end{array}$ & Powder & $\begin{array}{l}4 \% \mathrm{Al} \\
92 \% \mathrm{Si} \\
3 \% \mathrm{Fe}\end{array}$ & 1000 & 600 \\
\hline
\end{tabular}


156 The light source was a solid-state, single-mode laser diode (radiation output

157 max power $<50 \mu \mathrm{W}, 635 \mathrm{~nm}$ continuous wave, $\max$ power $<35 \mathrm{~mW})$. The

158 standard camera Marlin F-033B (Allied Vision Technologies GmbH,

159 Stadtroda, Germany) was used. All data were analyzed using the instrument

160 software (NanoSight ${ }^{\mathrm{TM}}$ version 2.2). The analysis with NTA was done on 7

161 videos with 1 min length each. The solution oxidation-reduction potential and

$162 \mathrm{pH}$ were measured in all exposure suspensions at the beginning and the end

163 of the tests. Total Fe concentration in stock suspensions was measured by

164 ICP-OES (Perkin Elmer, Optima 5300 DV) following microwave assisted

165 digestion under acidic conditions $(3.7 \% \mathrm{HCl})$.

166

$167 \quad 2.3$ Ecotoxicological test battery

168 A test battery of eight tests (see Table 2) was used to assess and rank the

169 nanomaterials listed in Table 1. Dilutions series were made from stock

170 suspensions and tested in concentrations up to $1 \mathrm{~g} / \mathrm{L}$. For some tests, higher

171 concentrations were assessed, including the root elongation test with radish

172 Raphanus sativus, ryegrass Lolium multiflorum (up to $10 \mathrm{~g} / \mathrm{L}$ ) and the

173 earthworm mortality test with Eisenia fetida (up to $25 \mathrm{~g} / \mathrm{L}$ ). Full tests

174 protocols are enclosed in the supplementary information. 
176 Table 2 Organisms and testing endpoints of the eight ecotoxicity tests in the test 177 battery.

\begin{tabular}{|c|c|c|c|c|}
\hline Organism & Species & Duration & Endpoint & Reference \\
\hline Bacteria & Vibrio fischeri & $15 \mathrm{~min}$ & $\begin{array}{l}\text { Decrease in } \\
\text { bioluminescence }\end{array}$ & ISO11348-3 \\
\hline Bacteria & Escherichia coli & $6 \mathrm{~h} / 24 \mathrm{~h}$ & Growth/Cell viability & - \\
\hline Algae & $\begin{array}{l}\text { Pseudokirchneri } \\
\text { ella subcapitata }\end{array}$ & $48 \mathrm{~h}$ & $\begin{array}{l}\text { Growth rate } \\
\text { inhibition }\end{array}$ & OECD 201 \\
\hline Algae & $\begin{array}{l}\text { Chlamydomonas } \\
\text { sp. }\end{array}$ & $48 \mathrm{~h}$ & $\begin{array}{l}\text { Photosynthesis } \\
\text { efficiency }\end{array}$ & \\
\hline Crustacean & Daphnia magna & $48 \mathrm{~h}$ & Immobilization & OECD 202 \\
\hline Earthworm & Eisenia fetida & $48 \mathrm{~h}$ & Mortality & OECD 207 \\
\hline Oligochaete & $\begin{array}{l}\text { Lumbriculus } \\
\text { variegatus }\end{array}$ & $96 \mathrm{~h}$ & Mortality & OECD $225^{\mathrm{a}}$ \\
\hline Plant & $\begin{array}{l}\text { Raphanus } \\
\text { sativus, Lolium } \\
\text { multiflorum }\end{array}$ & $6 \mathrm{~d}$ & Root elongation & OECD 208 \\
\hline
\end{tabular}

$178{ }^{\mathrm{a}}$ modified to short term water-phase exposure

179

1803 Results

$181 \quad 3.1$ Characterization

182 Table 3 provides an overview of the characterization of the Fe nanomaterials

183 in deionized water. Differences in size distribution were observed, with NTA

184 generally finding a lower average size than DLS. Based on zeta potential

185 measurements, Nano-Goethite and Trap-Ox Fe-zeolites showed higher

186 aqueous stability than FerMEG12 and Carbo-Iron ${ }^{\circledR}$, however sedimentation of

187 the Trap-Ox Fe-zeolites was also observed. In the more complex aquatic test

188 media, DLS measurements proved difficult due to particle sedimentation of

189 all tested materials. This violates the principle behind DLS for size 
190 distribution measurements as the particles are affected by gravitational

191 movement and not just Brownian movement and no reliable estimation of

192 size distribution could be made. Characterization with DLS also revealed that

193 all particle suspensions had a very broad size distribution with polydispersity

194 indexes around 1, which also undermines the use of DLS measurements to

195 characterize the suspensions.

196

$197 \quad 3.2$ Ecotoxicity

198 Almost all of the tests conducted showed no toxicity of the tested Fe

199 nanomaterials at concentrations up to $100 \mathrm{mg} / \mathrm{L}$, which is the cutoff value for 200 hazard labeling in the EU. Only FerMEG12 gave rise to toxicity at 201 concentrations below $100 \mathrm{mg} / \mathrm{L}$. Effects were seen in the $6 \mathrm{~h}$ growth 202 inhibition test with $E$. coli (Figure 1), the $6 \mathrm{~d}$ root elongation test with $R$. 203 sativus (Figure 2) and $96 \mathrm{~h}$ mortality test with L. variegatus (Figure 3 ).

204 The growth rate $\left(\mathrm{h}^{-1}\right)$ of Gram-negative E. coli was not significantly affected 205 in the presence of Carbo-Iron ${ }^{\circledR}$, Nano-Goethite and Trap-Ox Fe-zeolites at 206 any of the tested concentrations (Figure 1). A significant effect on E. coli 207 growth rate was observed for FerMEG12, from concentrations as low as 50 $208 \mathrm{mg} / \mathrm{L}(\mathrm{P}<0.001)$, and for magnetite at the highest concentration tested $(1000$ $209 \mathrm{mg} / \mathrm{L}, \mathrm{P}<0.05)$. 
211 Table 3 Characterization of the four tested nanomaterials dispersed in deionized 212 water at $100 \mathrm{mg} / \mathrm{L}$. Samples were characterized 2 and $144 \mathrm{~h}$ after dispersion and 213 analyzed by DLS for hydrodynamic diameter and zeta-potential. NTA analysis was 214 performed in samples $2 \mathrm{~h}$ after dispersion.

\begin{tabular}{|l|c|c|c|c|c|}
\hline Nanomaterial & \multicolumn{2}{|c|}{$\begin{array}{c}\text { DLS Hydrodynamic } \\
\text { diameter } \\
\text { (z-average; } \mathrm{nm})\end{array}$} & \multicolumn{2}{|l|}{ Zeta-potential $(\mathrm{mV})$} & $\begin{array}{c}\text { NTA Average size } \\
\text { (mode average; } \\
\text { nm) }\end{array}$ \\
\cline { 2 - 5 } & $2 \mathrm{~h}$ & $144 \mathrm{~h}$ & $2 \mathrm{~h}$ & $144 \mathrm{~h}$ & \\
\hline FerMEG12 & 480 & 720 & 12 & 1.5 & 210 \\
\hline Carbo-Iron $^{\circledR}$ & 1300 & 500 & -15 & -17 & 120 \\
\hline Nano-Goethite & 230 & 270 & -41 & -44 & - \\
\hline $\begin{array}{l}\text { Trap-Ox } \\
\text { Fe-zeolites }\end{array}$ & $780^{*}$ & $780^{*}$ & -65 & -60 & 250 \\
\hline
\end{tabular}

-: No data

$216 *$ : sedimentation after suspension in deionized water occurred

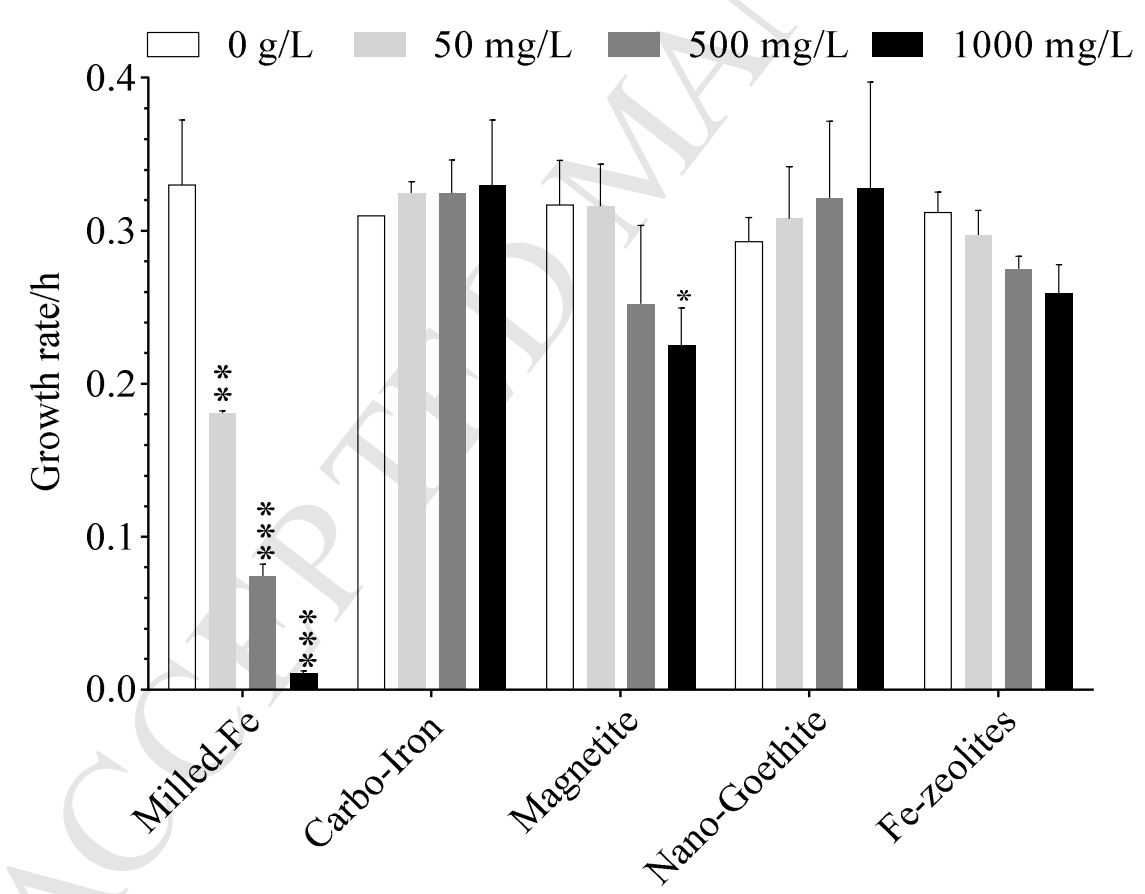

219 Figure 1 Growth rate of E. coli after 6h exposure to FerMEG12, Carbo-Iron ${ }^{\circledR}$, 220 magnetite, Nano-Goethite and Trap-Ox Fe-zeolites at 0, 50, 500 and $1000 \mathrm{mg} / \mathrm{L}$. 221 Asterisks indicate treatments that differ significantly from controls (ANOVA and 222 Dunnett's test, $\mathrm{n}=3)$. Significance levels were set at $\mathrm{P}<0.05(*), \mathrm{P}<0.001(* *)$ and $223 \mathrm{P}<0.0001(* * *)$. 

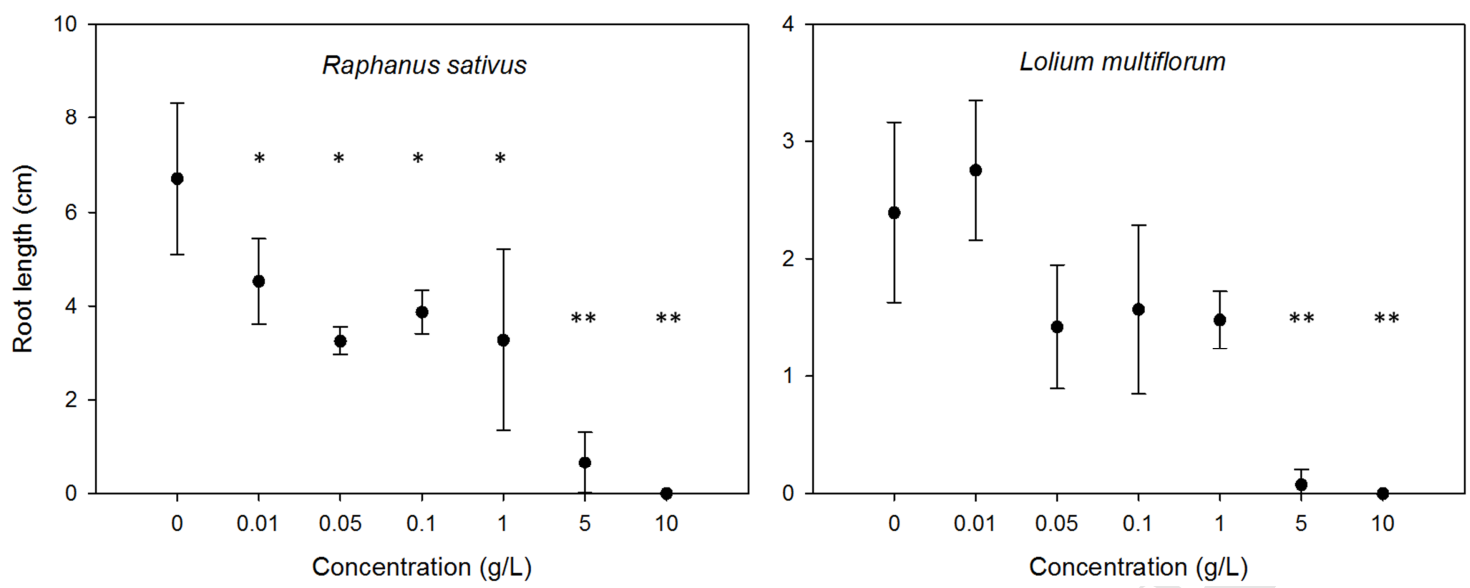

Figure 2 Root length of radish (Raphanus sativus) and ryegrass (Lolium multiflorum) exposed to various nominal Fe concentrations from FerMEG12

228 particles for $6 \mathrm{~d}$. Asterisks indicate treatments that differ significantly from controls 229 (Holm-Sidak, $\mathrm{n}=3, \mathrm{P}<0.05(*), \mathrm{P}<0.001(* *))$.

231 The root elongation of $R$. sativus was reduced by $33 \%$ by FerMEG12 232 particles at a nominal Fe concentration as low as $10 \mathrm{mg} / \mathrm{L}$. Root elongation 233 was increasingly reduced in a concentration-dependent manner and 234 completely inhibited at $10 \mathrm{~g} / \mathrm{L}$ (Figure 2, left). The root elongation of $L$. 235 multiflorum was significantly reduced at nominal Fe concentrations $>1 \mathrm{~g} / \mathrm{L}$, 236 and completely inhibited at $10 \mathrm{~g} / \mathrm{L}$ (Figure 2, right). The $\mathrm{pH}$ of the exposure 237 suspensions at the beginning of the experiment was $6.0 \pm 0.5$ over the whole 238 concentration range. In contrast, the oxidation reduction potential, measured 239 in exposure suspensions at the beginning of the experiment, was dramatically 240 different among concentrations and ranged from $+250 \mathrm{mV}$ (control), $+50 \mathrm{mV}$ 241 (0.01-0.1 g/L), to $-590 \mathrm{mV}$ (5 and $10 \mathrm{~g} / \mathrm{L})$. 


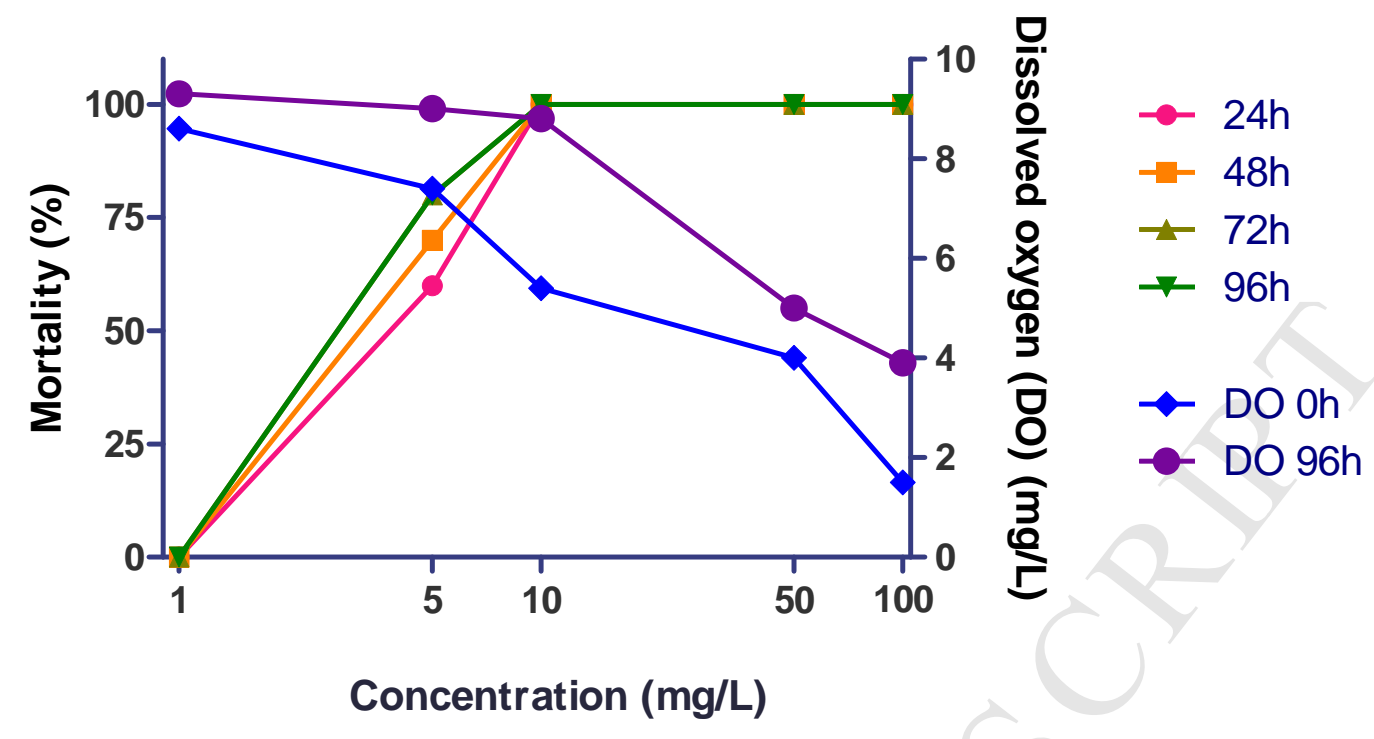

242

243

244

245

246

\subsection{Technical challenges of ecotoxicity testing of}

254 The higher concentrations of Fe nanomaterials did in several cases influence

255 the measurement principles or assumptions behind the tests. Especially the 256 turbidity of the suspensions caused issues with limited light transmission 
257 through the suspensions. In the $V$. fischeri test, the quantification of the

258 bioluminescence could be influenced by quenching of the emitted light before

259 it reaches the detector. This can easily be measured in a double vial setup that

260 ensures no actual bacterial exposure to the suspension, with the inner vial

261 containing the bacteria. A way to account for this is by spiking the

262 suspension with $V$. fischeri emitting a known amount of bioluminescence. In

263 this way, the added bacteria can act as an internal standard and the effect of

264 quenching can be estimated and corrected for. Using this method, it was clear

265 that the tested materials did quench light emission, giving rise to potential

266 erroneous conclusions if unaccounted for.

267 For the algal growth inhibition, issues with the quantification of algal 268 biomass also started to appear at higher concentrations (>100 mg/L). At high

269 Fe concentrations the fluorescence spectrum was altered significantly and 270 obfuscated the presence and the size of the chlorophyll peak. During the 271 testing, the turbidity can also prevent the algae to obtain sufficient light for 272 exponential growth, a shading effect that can be difficult to account for 273 (Hjorth et al., 2015).

274 In the tests with D. magna and L. variegatus, oxidation, aggregation, 275 precipitation and ultimately sedimentation of $\mathrm{Fe}$ resulted in a change of 276 exposure route (which was intended to be through the water phase alone) 277 directly affecting the mobility of D. magna. Due to the described 278 stratification of Fe particles, L. variegatus was exposed to an increased 
279 concentration, as both the particles and the oligochaeta stay at the bottom of 280 the beaker.

\section{Discussion}

\subsection{Ecotoxicity of Fe nanomaterials}

284 Based on the performed ecotoxicity tests in the present study, only the 285 FerMEG12 particles would be classified as toxic to aquatic organisms in 286 accordance to the CLP regulation. As none of the other tested materials 287 showed toxicity below $100 \mathrm{mg} / \mathrm{L}$, none of them would receive any 288 environmental hazard classification. The highest toxicity of the FerMEG12 289 particles was observed towards the oligochaeta $L$. variegatus. However 290 particle sedimentation during the test consequently exposed $L$. variegatus to

291 higher Fe concentrations than what was initially dispersed, which could 292 explain why toxicity was observed for $L$. variegatus and not e.g. for $D$. 293 magna which spends more time in the water column. Ageing the particles for $2941 \mathrm{~h}$ in media alleviated the toxicity, which is in agreement with an earlier 295 study on milled particles reporting low toxicity after oxidation (Köber et al., 296 2014). Similarly, a recent study on zebrafish found no adverse effects of aged 297 Carbo-Iron ${ }^{\circledR}$ (Weil et al., 2015). 
298 The FerMEG12 particles were also tested in the standard algal test with $P$.

299 subcapitata with acute effects evidenced by a decrease in fluorescence right 300 after the onset of the test (data not shown). However, during the incubation

301 period the algal population recovered and exhibited growth rates similar (or 302 higher) than the non-exposed controls. As the only material out of the four 303 tested, FerMEG12 was dispersed in a solvent (ethylene glycol) and although 304 ethylene glycol in itself showed no toxicity when tested, it seems to have 305 preserved the reactivity of FerMEG12's elemental iron. Other studies confirm 306 the toxicity of freshly prepared, non-oxidized nZVI. For instance, Keller et 307 al. (2012) studied the response of microalgae and D. magna exposed to 308 NANOFER STAR and 25S. D. magna proved the most sensitive with LOEC 309 values of $0.5 \mathrm{mg} / \mathrm{L}$ for the NANOFER STAR and NANOFER $25 \mathrm{~s}$, compared 310 to a $\mathrm{LOEC}$ of $1 \mathrm{mg} / \mathrm{L}$ for $\mathrm{Fe}^{2+}$. Whereas the growth of the marine microalga $I$. 311 galbana was inhibited after exposure to NANOFER $25 \mathrm{~s}$ starting at $3 \mathrm{mg} / \mathrm{L}$ 312 (Keller et al., 2012), no effect was observed for NANOFER STAR at 313 concentrations up to $100 \mathrm{mg} / \mathrm{L}$ and effects from dissolved Fe did not occur at 314 concentrations lower than $50 \mathrm{mg} / \mathrm{L}$. For the freshwater microalgae, $P$. 315 subcapitata, $\mathrm{Fe}^{2+}$ exposure proved the most toxic with a LOEC value of 5 $316 \mathrm{mg} / \mathrm{L}$, which was lower than for any of the particles or $\mathrm{Fe}^{3+}$ (Keller et al., 317 2012).

318 NANOFER 25s has also been found to affect the growth of the nematode $C$. 319 elegans at $0.5 \mathrm{mg} / \mathrm{L}$, whereas at $5 \mathrm{mg} / \mathrm{L}$ a decrease in survival and 
320 reproduction occurred. However, when tested in soil, no toxicity to $C$.

321 elegans was observed for NANOFER $25 \mathrm{~s}$ at concentrations up to $17 \mathrm{mg} / \mathrm{g}$.

322 On the contrary, their growth and reproduction increased (Saccà et al., 2014).

323 Similarly, the survival of the earthworm, E. fetida, was not affected by nZVI 324 even at $3 \mathrm{~g} / \mathrm{kg}$, although DNA damage and lipid oxidation was observed 325 (Yirsaw et al., 2016).

326 Chen et al. (2011) investigated continuous exposure of carboxymethyl 327 cellulose stabilized nZVI (CMC-nZVI) towards medaka fish larvae and 328 concluded that the toxicity was caused by hypoxia, $\mathrm{Fe}^{2+}$ toxicity, and ROS329 mediated oxidative damage. In their experiment $\mathrm{Fe}^{2+}$ proved the most acutely 330 toxic with $100 \%$ mortality at $75 \mathrm{mg} / \mathrm{L}$. In a similar study, Chen et al. (2012) 331 reported $\mathrm{Fe}^{2+}$ being the most toxic form of $\mathrm{Fe}$ tested, followed by $\mathrm{CMC}$ 332 nZVI, nZVI and lastly the aged nZVI. Yet in Chen et al. (2013) CMC-nZVI 333 had a higher acute toxicity than both $\mathrm{Fe}^{2+}$ and aged nZVI.

334 Marsalek et al. (2012) have reported low aquatic toxicity for NANOFER 25 335 with $\mathrm{EC}_{50}>1 \mathrm{~g} / \mathrm{L}$ for $D$. magna and $>2.5 \mathrm{~g} / \mathrm{L}$ for fish (P. reticulate) and 336 similar values for willows (S. alba), duckweed (L. minor), and microalgae ( $D$. 337 subspicatus). Effects on the cyanobacteria $M$. aeruginosa were observed at 338 the lowest concentrations in the test battery and with an $\mathrm{EC}_{50}$-value of 50 $339 \mathrm{mg} / \mathrm{L}$.

340 Although there are signs of increased ecotoxicity of nZVI compared to $\mathrm{Fe}^{2+}$, 341 which seems rational due to the additional oxidative capacity of $\mathrm{Fe}^{0}$, the 
342 opposite is also sometimes the case. However none of the studies in the

343 scientific literature on Fe nanomaterials have reported a higher toxicity than

344 what has been shown for dissolved Fe (Johnson et al., 2007). It seems likely

345 that varying, and generally lower, bioavailability of nZVI in media has the 346 potential to offset any increase in toxicity compared to dissolved Fe.

\subsection{Environmental risk assessment of $\mathrm{Fe}$ in surface}

350 Whereas hazard and risk assessment of Fe nanomaterials is a novel task, the

351 toxic effects of $\mathrm{Fe}$ and $\mathrm{Fe}$ salts on aquatic life is well described. $\mathrm{Fe}^{2+}$ is

352 generally considered bioavailable and can induce toxicity in aquatic

353 organisms, whereas when oxidized to $\mathrm{Fe}^{3+}$ it hydrolyses and precipitates out

354 of solution as hydroxides at normal $\mathrm{pH}$, which then can give rise to indirect,

355 physical effects (Vuori, 1995). Ecotoxicity testing of Fe has traditionally

356 made a distinction between total $\mathrm{Fe}$ and dissolved $\mathrm{Fe}$, ideally signifying $\mathrm{Fe}^{2+}$,

357 however in practice meaning anything that passes through a $0.45 \mu \mathrm{m}$ filter,

358 which includes colloidal Fe(III) stabilized mostly by organic material (Vuori,

359 1995) and Fe(III) complexed by organic ligands. In this way, many tests have

360 already, indirectly, assessed the toxicity of suspended $\mathrm{Fe}$ in the nano range.

361 Even for $\mathrm{Fe}$, hazard and risk assessment as well as setting appropriate 
362 environmental quality standards (EQS) has been difficult for decades due to

363 this redox cycling, inorganic speciation, complexation and precipitation.

364 As an example, the company American Electric Power (AEP) argued in 1983

365 that the USEPA water quality standard of $1 \mathrm{mg} / \mathrm{L}$ for Fe was too low, stating

366 that field data showed that Fe concentrations "need to be far over $1 \mathrm{mg} / \mathrm{L}$ to

367 adversely affect" aquatic life, and that toxicity testing is not fit to assess Fe

368 toxicity (Loeffelman et al., 1985). AEP also called for a use of $\mathrm{Fe}^{2+}$, and not

369 total Fe, as the foundation for setting the water quality standard, based on the

370 fact that $\mathrm{Fe}^{2+}$ is the bioavailable fraction of $\mathrm{Fe}$.

371 More recently, Linton et al. (2007) acknowledged that the USEPA "metal 372 policy" generally is to derive "aquatic life criteria" based on the dissolved 373 metal and therefore $\mathrm{Fe}$ should be regulated based on $\mathrm{Fe}^{2+}$ toxicity. Yet, it 374 makes sense to use field data on total $\mathrm{Fe}$, as lab-based toxicity testing of $\mathrm{Fe}$ is 375 poor at assessing colloidal and indirect effects such as the impact on 376 respiration and food consumption. With reference to a review by Vouri 377 (1995) who states "the effect of Fe on aquatic animals and their habitats are 378 mainly indirect", Linton et al. (2007) argue that field studies therefore would 379 do a better job of assessing the overall environmental impact of $\mathrm{Fe}$. 380 Accordingly, the assessment still has a foundation in field observations partly 381 due to this issue of indirect effects (Linton et al., 2007). Based on additional 382 field data, Linton et al. (2007) however proposed a new and differentiated 
383 EQS of $0.21 \mathrm{mg} / \mathrm{L}$ for sensitive groups and $1.74 \mathrm{mg} / \mathrm{L}$ for "slight to moderate 384 changes" in the aquatic community.

385 In Europe, the Environment Agency in England proposed a new EQS for Fe 386 in 2007 under the Water Framework Directive (Johnson et al., 2007). A long 387 term PNEC of $16 \mu \mathrm{g} / \mathrm{L}$ was derived, based on a NOEC value of $0.16 \mathrm{mg} / \mathrm{L}$ 388 obtained in a 21-d study on D. magna. Similarly, a $96 \mathrm{~h}$ study on brook trout 389 (S. fontinalis) with a $\mathrm{LC}_{50}$ value of $0.41 \mathrm{mg} / \mathrm{L}$ gave rise to a short term PNEC 390 of $41 \mu \mathrm{g} / \mathrm{L}$. They rationalized the use of the considerably lower PNEC values 391 with the emergence of new data as well as the fact that the old EQS was 392 based on field data and not on standardized toxicity tests.

393 In response to this, Crane et al. (2007) stated that $16 \mu \mathrm{g} / \mathrm{L}$ was "substantially 394 below concentrations associated with impaired invertebrate assemblages in 395 the field". Based on their analysis of data from 253 sites in England and 396 Wales, Crane et al. (2007) proposed an EQS between 43-250 $\mu \mathrm{g} / \mathrm{L}$ based on 397 dissolved Fe. In 2012, the UK Technical Advisory Group proposed an EQS 398 of $0.73 \mathrm{mg} / \mathrm{L}$ total $\mathrm{Fe}$, based on field data, in a very thorough review (Peters 399 et al., 2012). The suggested EQS from the Environment Agency of $16 \mu \mathrm{g} / \mathrm{L}$ 400 was described as well below background levels and therefore "not adopted 401 for regulatory use".

402 In accordance with Linton et al. (2007), Peters et al. (2012) state that the 403 effects of Fe are difficult to isolate and, in contrast to most metals, we cannot 404 just focus on the dissolved fraction as there is also a physical effect from the 
405 total Fe, which perhaps could even be dominating. This line of reasoning also

406 advocates for the use of total $\mathrm{Fe}$ as the dose metric for ecotoxicity studies on

407 Fe nanomaterials.

408

409

\subsection{Applicability of standardized ecotoxicity tests}

410 for hazard identification of Fe nanomaterials

411 As shown above, the current consensus seems to move away from using

412 standardized ecotoxicity tests on Fe for risk assessment purposes; rather the

413 use of field data and mesocosm studies are encouraged. Peters et al. (2012)

414 point towards the issue of Fe solubility as well as the issue with assessing 415 physical effects as the key points against using standardized ecotoxicity 416 testing of Fe. Wess (2015) also questions the adequacy of ecotoxicity tests on 417 Fe to inform risk assessment as they fail to uphold various criteria for 418 assessing causation, e.g. issues with establishing dose response relationships 419 and incoherence with field data. If these ecotoxicity tests are not suitable for

420 Fe salts due to precipitation and exposure control issues, then clearly they are 421 not suitable to assess Fe nanomaterials, which by definition are not dissolved 422 entities.

423 However, having the test limitations and challenges in mind, such as the ones

424 mentioned in section 3.3, as well as the general testing considerations in 425 nanoecotoxicology (Petersen et al., 2014; Skjolding et al., 2016) and indirect 
426 physical effects (Sørensen et al., 2015), standardized ecotoxicity tests can

427 still provide valuable information, as a screening and ranking tool for hazard

428 identification. Trying to overcome these limitations will sometimes result in

429 deviations from the standard tests, which at times are necessary to obtain

430 meaningful data. Additionally, the information generated from standardized

431 ecotoxicity tests is still required by regulatory agencies to achieve market 432 access.

433 On the other hand, as shown for Fe salts, standardized ecotoxicity tests are

434 challenged in terms of their usefulness and accuracy for site-specific and case 435 oriented risk assessments, and it is recommended to rely more on field data 436 when assessing the environmental impact of Fe (EC, 2011). The relevance of 437 standard organisms for site-specific risk assessment is questionable for 438 remediation cases, as the extrapolation value from these organisms to 439 ecosystems may be low. In addition, the transformation of the pristine 440 material to the oxidized form expected in the environment and the 441 corresponding change in toxicity is also better assessed in the field. As such, 442 it makes sense to rely less on laboratory ecotoxicity testing and instead 443 incorporate mesocosm and field data into site-specific risk assessment of $\mathrm{Fe}$ 444 nanomaterials. 


\section{Conclusion and recommendations}

446 Ecotoxicity testing of four nanomaterials engineered for sub-surface

447 remediation revealed low toxicity for all $\mathrm{Fe}$ oxides materials as well as

448 Carbo-Iron $^{\circledR}$, and the results do not lead to any hazard classification

449 according to current EU regulation. FerMEG12 was the only material

450 exhibiting toxicity towards bacteria and plants at $50 \mathrm{mg} / \mathrm{L}$ and oligochaetes at

$4515 \mathrm{mg} / \mathrm{L}$. Standard ecotoxicity testing of nanoparticles has in general proven

452 technically difficult and it may be questioned whether proper hazard

453 identification of engineered nanoparticles needed for environmental risk

454 assessment is currently feasible. Aggregation, agglomeration, sedimentation,

455 shading, and other physical effects are known to confound the measuring

456 principles behind the tests and these interferences were also observed for the

457 tested particles. This was pronounced for tests on algae, bacteria, and

458 crustaceans and requires inclusion of additional controls to ensure a correct

459 data interpretation. While $\mathrm{Fe}^{0}$ nanomaterials have the potential to be toxic at

460 low concentrations, a potential environmental impact downstream of the

461 injection of $\mathrm{Fe}$ nanomaterials seems more likely to originate from the large

462 amount of $\mathrm{Fe}$ injected in in-situ remediation, than from novel particle related

463 effects, especially since $\mathrm{Fe}$ is abundant in nature as particulate matter. In

464 conclusion we recommend: 
465

466 and classification purposes. Testing Fe nanoparticles at higher concentrations

467 not only decreases the environmental relevance, but also increases the

468 influence of physical effects such as turbidity and concentration-dependent 469 agglomeration. Therefore, the main focus in testing should be on 470 concentrations $<100 \mathrm{mg} / \mathrm{L}$, and care should be taken when conducting 471 ecotoxicological testing of Fe nanomaterials at higher concentrations.

472

473 474 of the standard test setups for which a constant exposure during incubation is 475 required. These issues are currently under scrutiny in the OECD WPMN and 476 in several EU projects (Lynch, 2016). We recommend the use of these tests 477 for hazard identification and ranking, where these tests still provide valuable 478 information.

479

480

- For Fe nanomaterials, agglomeration and sedimentation challenge the validity crazard identification and ranking, where these tests still provide valuable

- We recommend studying the effects of $\mathrm{Fe}$ nanomaterials in more 81 environmentally realistic conditions to support site-specific hazard 82 assessment. E.g. through testing of relevant organisms, media and more 83 complex testing systems closer related to the field, as the scope of 84 standardized ecotoxicity testing is limited and not designed to assess the $85 \quad$ indirect effects of Fe exposure. 
487

488

490

49

492

493

494

495

496

497

499

500

501

502

503

504

505

506

507

\section{Acknowledgements}

\section{$498 \quad 6$ References} at

This project has received funding from the European Union's Seventh Framework Programme for research, technological development and demonstration under grant agreement no 309517 (NanoRem). RH is also funded by the project 'Integrated water technology' - an initiative between the Korea Advanced Institute of Science and the Technical University of Denmark. NN and AŠ acknowledge the assistance provided by the Research Infrastructure NanoEnviCz, supported by the Ministry of Education, Youth and Sports (CZ) under project No. LM2015073. The authors are also grateful to E. Maremonti for her help during plant growth testing.

Bardos, P., Bone, B., Daly, P., Elliott, D., Jones, S., Lowry, G. \& Merly, C. (2014). A Risk / Benefit Appraisal for the Application of Nano-Scale Zero Valent Iron (nZVI) for the Remediation of Contaminated Sites. WP9 NanoRem. Available

http://www.nanorem.eu/Stream.aspx?p=/App_Data/docs/user7Gallery/NANOR EM\%20NZVI\%20risk\%20benefit\%20issues\%20paper\%20FINAL_2.0.pdf

Chen, P.-J., Su, C.-H., Tseng, C.-Y., Tan, S.-W. \& Cheng, C.-H. (2011). Toxicity assessments of nanoscale zerovalent iron and its oxidation products in medaka (Oryzias latipes) fish. Marine pollution bulletin. 63 (5-12). p.pp. 339-46. 
508 Chen, P.-J., Tan, S.-W. \& Wu, W.-L. (2012). Stabilization or oxidation of nanoscale zerovalent iron at environmentally relevant exposure changes bioavailability and toxicity in medaka fish. Environmental Science \& Technology. 46 (15). p.pp. 8431-9.

512 Chen, P.-J., Wu, W.-L. \& Wu, K.C.-W. (2013). The zerovalent iron nanoparticle causes higher developmental toxicity than its oxidation products in early life stages of medaka fish. Water research. 47 (12). p.pp. 3899-909.

Crane, M., Kwok, K.W.H., Wells, C., Whitehouse, P. \& Lui, G.C.S. (2007). Use of field data to support European Water Framework Directive quality standards for dissolved metals. Environmental Science \& Technology. 41 (14). p.pp.

EC, (2011). Common Implementation Strategy for the Water Framework Directive (2000/60/EC). Guidance Document No. 27. Technical Guidance For Dericing Environmental Quality Standards. European Commission, Brussels, Belgium.

522 $5014-5021$.

El-Temsah, Y.S., Sevcu, A., Bobcikova, K., Cernik, M. \& Joner, E.J. (2016). DDT degradation efficiency and ecotoxicological effects of two types of nano-sized zero-valent iron (nZVI) in water and soil. Chemosphere. 144. p.pp. 2221-2228.

Grieger, K.D., Fjordbøge, A., Hartmann, N.B., Eriksson, E., Bjerg, P.L. \& Baun, A. (2010). Environmental benefits and risks of zero-valent iron nanoparticles (nZVI) for in situ remediation: risk mitigation or trade-off? Journal of contaminant hydrology. 118 (3-4). p.pp. 165-83.

Grieger, K.D., Hjorth, R., Rice, J., Kumar, N. \& Bang, J. (2015). Nano- 
remediation: tiny particles cleaning up big environmental problems. Blog entry for the International Union for Conservation of Nature (IUCN), Available at http://cmsdata.iucn.org/downloads/nanoremediation.pdf.

533

534

Henderson, A.D. \& Demond, A.H. (2007). Long-Term Performance of Zero-Valent Iron Permeable Reactive Barriers: A Critical Review. Environmental Engineering Science. 24 (4). p.pp. 401-423.

Hjorth, R., Sørensen, S.N., Olsson, M.E., Baun, A. \& Hartmann, N.B. (2015). A certain shade of green: Can algal pigments reveal shading effects of nanoparticles? Integrated Environmental Assessment and Management. 15(1), p.pp 200-202.

Johnson, I., Sorokin, N., Atkinson, C., Rule, K., Hope, S.-J. \& Agency, E. (2007). Preconsultation report: Proposed EQS for Water Framework Directive Annex VIII substances: iron (total dissolved). Environment Agency, Bristol, UK.

Karn, B., Kuiken, T. \& Otto, M. (2009). Nanotechnology and in situ remediation: a review of the benefits and potential risks. Environmental health perspectives. 117 (12). p.pp. 1813-31.

Keller, A. a, Garner, K., Miller, R.J. \& Lenihan, H.S. (2012). Toxicity of nano-zero valent iron to freshwater and marine organisms. PloS one. 7 (8). p.pp 1-10.

Köber, R., Hollert, H., Hornbruch, G., Jekel, M., Kamptner, A., Klaas, N., Maes, H., Mangold, K.M., Martac, E., Matheis, A., Paar, H., Schäffer, A., Schell, H., Schiwy, A., Schmidt, K.R., Strutz, T.J., Thümmler, S., Tiehm, A. \& Braun, J. (2014). Nanoscale zero-valent iron flakes for groundwater treatment. 
553 Linton, T., Pacheco, M., McIntyre, D., Clement, W. \& Goorich-Mahoney, J. (2007).

554 Development of bioassessment-based benchmarks for iron. Environmental $555 \quad$ Toxicology. 26 (6). p.pp. 1291-1298.

556 Loeffelman, P.H., Van Hassel, J.H., Arnold, T.E. \& Hendricks, J.C. (1985). A new 557 approach for regulating iron in water quality standards. Aquatic Toxicology 558 and Hazard assessment: Eight Symposium. ASTM STP 891. p.pp. 137-152.

559 Lynch, I. (2016). Compendium of Projects in the European NanoSafety Cluster.

5602016 edition. Available at

561 http://www.nanosafetycluster.eu/www.nanosafetycluster.eu/home/european562 nanosafety-cluster-compendium.html

563 Marsalek, B., Jancula, D., Marsalkova, E., Mashlan, M., Safarova, K., Tucek, J. \& 564 Zboril, R. (2012). Multimodal action and selective toxicity of zerovalent iron 565 56646 (4). p.pp. 2316-2323. nanoparticles against cyanobacteria. Environmental Science and Technology.

567 Mueller, N.C., Braun, J., Bruns, J., Černík, M., Rissing, P., Rickerby, D. \& 568 Nowack, B. (2012). Application of nanoscale zero valent iron (NZVI) for groundwater remediation in Europe. Environmental science and pollution research international. 19. p.pp. 550-558.

571 Peters, A., Merrington, G., Simpson, P. \& Crane, M. (2012). Proposed Quality 572 Standards for Iron in Freshwaters Based on Field Evidence. Water Framework 573 Directive - United Kingdom Technical Advisory Group (WFD-UKTAG). 
Edinburgh, Scotland.

575

576

577

578

579

580

Petersen, E.J., Henry, T.B., Zhao, J., Maccuspie, R.I., Kirschling, T.L., Dobrovolskaia, M.A., Hackley, V., Xing, B. \& White, J.C. (2014). Identification and avoidance of potential artifacts and misinterpretations in nanomaterial ecotoxicity measurements. Environmental science \& technology. 48. p.pp. $4226-4246$.

Saccà, M.L., Fajardo, C., Costa, G., Lobo, C., Nande, M. \& Martin, M. (2014). Integrating classical and molecular approaches to evaluate the impact of nanosized zero-valent iron (nZVI) on soil organisms. Chemosphere. 104. p.pp. 184-189.

Skjolding, L.M., Sørensen, S.N., Hartmann, N.B., Hjorth, R., Hansen, S.F. \& Baun, A. (2016). A Critical Review of Aquatic Ecotoxicity Testing of Nanoparticles The Quest for Disclosing Nanoparticle Effects. Angewandte Chemie International Edition. 55 (49). p.pp. 15224-15239.

Sørensen, S.N., Hjorth, R., Delgado, C.G., Hartmann, N.B. \& Baun, A. (2015). Nanoparticle toxicity - Physical and/or chemical effects? Integrated Environmental Assessment and Management. 11(4). p.pp. 722-724.

Vuori, K.-M. (1995). Direct and indirect effects on iron on river ecosystems. Annales Zoologici Fennici. (32). p.pp 317-329.

Wang, C.-B. \& Zhang, W. (1997). Synthesizing Nanoscale Iron Particles for Rapid and Complete Dechlorination of TCE and PCBs. Environmental Science \& Technology. 31 (7). p.pp. 2154-2156. 
596 Weil, M., Meißner, T., Busch, W., Springer, A., Kühnel, D., Schulz, R. \& Duis, K. 597 (2015). The oxidized state of the nanocomposite Carbo-Iron $₫$ causes no 598 adverse effects on growth, survival and differential gene expression in 599 zebrafish. Science of the Total Environment. 530-531. p.pp. 198-208.

600 Wess, R.A. (2015). The question of causation and adequacy - iron as an example of 601 intrinsic toxicity and other effects. Integrated Environmental Assessment and 602 Management. 12 (1). p.pp. 202-204.

603 Yan, W., Lien, H.-L., Koel, B.E. \& Zhang, W. (2013). Iron nanoparticles for 604 environmental clean-up: recent developments and future outlook. 605 Environmental Science: Processes \& Impacts. 15. p.pp. 63-77.

606 Yirsaw, B.D., Mayilswami, S., Megharaj, M., Chen, Z. \& Naidu, R. (2016). Effect 607 of zero valent iron nanoparticles to Eisenia fetida in three soil types. 608 Environmental Science and Pollution Research. 23 (10). p.pp. 9822-9831. 


\section{Highlights}

- This study summarizes the outcome of nanoecotoxicity testing in NanoRem.

- We assessed four novel engineered nanomaterials in an ecotoxicological test battery.

- Only one of the tested materials gave rise to toxicity below $100 \mathrm{mg} / \mathrm{L}$.

- Standardized testing is inadequate to inform site-specific risk assessment. 